\title{
Pola Kekerasan Senjata Api di Sulawesi Utara Periode 2012-2017
}

\author{
${ }^{1}$ Fauziyyah N. S. E. Djaafara \\ ${ }^{2}$ James F. Siwu \\ ${ }^{2}$ Erwin G. Kristanto
}

\author{
${ }^{1}$ Program Studi Pendidikan Dokter Fakultas Kedokteran Universitas Sam Ratulangi Manado \\ ${ }^{2}$ Bagian Kedokteran Forensik dan Medikolegal Universitas Sam Ratulangi Manado \\ Email: fauziyyahdj@gmail.com
}

\begin{abstract}
Injuries and deaths resulted from firearm violence are global public health issues. In Indonesia, many firearm violence cases are reported in areas with frequent conflicts. In North Sulawesi, especially in Manado City, reports of firearm violence have not been well documented. This study was aimed to determine the firearm violence pattern in North Sulawesi in the period of 2012-2017. This was andescriptive retrospective study. Data of gunshot wounds in North Sulawesi in the period of January 2012-July 2017 were obtained from visum et repertum of gunshot wound in death cases at the Department of Forensic and Medicolegal Prof. R. D. Kandou Hospital, medical records of patients in the Department of Surgery Prof. R. D. Kandou Hospital, and the Criminal Investigation Department of North Sulawesi Regional Police. There were 14 cases of gunshot wounds. All of the cases were males and dominated by productive age group. The highest number of gunshot cases occurred in Manado. From the visum et repertum and examinations, it was found that all cases had an entrance gunshot wound. Conclusion: In North Sulawesi, gunshot cases were found in males, most were in productive age, and had entrance gunshot wound.
\end{abstract}

Keywords: firearms, gunshot wounds, North Sulawesi

\begin{abstract}
Abstrak: Cedera dan kematian akibat kekerasan senjata api menjadi salah satu masalah kesehatan masyarakat secara global. Di Indonesia, kasus kekerasan senjata api banyak dilaporkan di daerah yang sering mengalami konflik. Di Provinsi Sulawesi Utara, khususnya Kota Manado laporan mengenai angka kejadian kekerasan senjata api belum tercatat dengan baik. Penelitian ini bertujuan untuk mengetahui gambaran pola kekerasan senjata api di Sulawesi Utara pada periode 2012-2017. Jenis penelitian ialah deskriptif retrospektif. Dari hasil pengumpulan data kasus luka tembak di Sulawesi Utara kurun waktu tersebut melalui penelusuran hasil visum et repertum pada kematian akibat luka tembak di Bagian Kedokteran Forensik dan Medikolegal RSUP Prof. Dr. R. D Kandou, rekam medik pasien di Bagian Ilmu Bedah RSUP Prof. Dr. R. D. Kandou, dan Bagian Reserse Kriminal Umum (Bareskrimum) Kepolisian Daerah Sulawesi Utara tercatat 14 kasus luka tembak yang terjadi di Sulawesi Utara. Secara keseluruhan kasus luka tembak terjadi pada laki-laki dan didominasi oleh kelompok usia produktif. Kasus penembakan terbanyak terjadi di Kota Manado. Dari hasil pemeriksaan dan visum et repertum, didapatkan hasil bahwa seluruh kasus merupakan gambaran luka tembak masuk. Simpulan: Di Sulawesi Utara, kasus luka tembak ditemukan pada jenis kelamin laki-laki, umumnya usia produktif, dengan luka tembak masuk.
\end{abstract}

Kata kunci: senjata api, luka tembak, Sulawesi Utara

Dewasa ini, cedera dan kematian akibat kekerasan senjata api menjadi salah satu masalah kesehatan masyarakat secara global. ${ }^{1}$ Hal ini timbul akibat meningkatnya angka kejadian kekerasan dengan menggunakan senjata api yang menyebabkan luka tembak. Menurut WHO, pada tahun 2001, diperkirakan terdapat lebih dari 500.000 
kasus luka tembak dalam setahun. Jumlah tersebut mewakili seperempat dari total perkiraan 2,3 juta kematian akibat kekerasan. Dari 500.000 kasus luka tembak, $42 \%$ merupakan kasus bunuh diri, $38 \%$ merupakan kasus pembunuhan dan $20 \%$ merupakan kasus perang dan konflik senjata. $^{2}$

Luka tembak merupakan penyebab kematian akibat kejahatan yang paling umum di Amerika Serikat. Luka tembak yang paling banyak dijumpai sebagai penyebab kematian adalah luka tembak akibat pembunuhan dan bunuh diri. Kasus kematian di negara ini dalam tahun selama periode 1980 sampai 2007, lebih kurang 32.300 jiwa. Kekerasan menggunakan senjata api menjadi penyebab kedua kematian terbesar setelah kendaraan bermotor. Laporan pada tahun 2007 menunjukkan angka kejadian luka tembak sebesar 10,2/100 ribu (67\% kasus pembunuhan, $50 \%$ kasus bunuh diri, $43 \%$ kasus perampokan, dan $21 \%$ kasus kecelakaan). ${ }^{3}$

Di Indonesia, kasus kekerasan senjata api banyak dilaporkan di daerah yang sering mengalami konflik. Menurut laporan Komisi untuk Orang Hilang dan Tindak Kekerasan (KontraS) tahun 2011-2013 tercatat 402 kasus penembakan. Tahun 2011 sebanyak 62 kejadian, tahun 2012 sebanyak 172 kejadian, dan tahun 2013 (Januari-Agustus) sebanyak 168 kejadian. Sebaran wilayah penembakan paling banyak terjadi di daerah konflik seperti Papua, Aceh dan Poso. Di Papua tercatat 98 kasus penembakan. Diantaranya; 26 penembakan dilakukan Polisi, sekitar 9 penembakan dilakukan TNI, dan 63 peristiwa dilakukan oleh OTK (orang tidak dikenal). Di Aceh, tercatat sedikitnya 22 peristiwa penembakan terjadi; sebanyak 11 peristiwa dilakukan oleh OTK, 8 peristiwa oleh anggota Polisi, dan 3 peristiwa oleh anggota TNI. ${ }^{4}$ Di Provinsi Sulawesi Utara, khususnya Kota Manado laporan mengenai angka kejadian kekerasan senjata api belum banyak tersedia, berbeda dengan laporan cedera akibat kecelakaan lalu lintas di Manado yang terjadi peningkatan, terutama di tahun $2007 .^{5}$
Penelitian ini bertujuan untuk mengetahui gambaran pola kekerasan senjata api di Sulawesi Utara pada periode 2012-2017.

\section{METODE PENELITIAN}

Jenis penelitian yang dilakukan ialah deskriptif retrospektif. Penelitian ini meggunakan data sekunder selang waktu Januari 2012-Juli 2017 di Bagian Ilmu Kedokteran Forensik Medikolegal dan Bagian Ilmu Bedah FK Unsrat- RSUP Prof. R. D. Kandou Manado.

Subjek penelitian ialah data kasus luka tembak akibat kekerasan senjata api dan surat keterangan Visum et Repertum (VeR) di Bagian Ilmu Kedokteran Forensik Medikolegal FK Unsrat-RSUP Prof. R. D. Kandou Manado, Bagian Ilmu Bedah FK Unsrat-RSUP Prof. R. D. Kandou Manado, dan Kepolisian Daerah Sulawesi Utara. selama periode Januari 2012 - Juli 2017.

\section{HASIL PENELITIAN}

Dari hasil pengumpulan data kasus luka tembak di Sulawesi Utara kurun waktu Januari 2012-Juli 2017 melalui penelusuran hasil visum et repertum pada kematian akibat luka tembak di Bagian Kedokteran Forensik dan Medikolegal RSUP Prof. dr. R. D Kandou, rekam medik pasien di Bagian Ilmu Bedah RSUP Prof. dr. R. D. Kandou, dan Bagian Reserse Kriminal Umum (Bareskrimum) Kepolisian Daerah Sulawesi Utara tercatat 14 kasus luka tembak yang terjadi di Sulawesi Utara dengan perincian sebagai berikut: 3 kasus $(21,43 \%)$ di tahun 2012,1 kasus $(7,14 \%)$ di tahun 2013, 1 kasus $(7,14 \%)$ di tahun 2014, 2 kasus $(14,29 \%)$ di tahun 2015, 5 kasus $(35,71 \%)$ di tahun 2016, dan 2 kasus (14,29\%) di tahun 2017 (Tabel 1)

Karakteristik sosiodemografik kasus luka tembak dapat dilihat pada Tabel 2. Semua kejadian terjadi pada laki-laki yakni $14(100 \%)$ kasus. Kebanyakan berada pada rentang usia 25-44 tahun yaitu 7 (50\%) kasus, sebagian kecil terdapat pada rentang usia 15-24 tahun yakni 3 kasus (21.43\%); tidak dijumpai kasus luka tembak pada usia <5 tahun dan 5-14 tahun, serta terdapat 4 kasus yang tidak memiliki data 
usia. Sebagian besar penembakan terjadi di Manado yakni $12(85,71 \%)$ kasus, sedangkan sebagian kecil lainnya di Minahasa Induk dan Bolaang Mongondow, masingmasing $1(7,14 \%)$ kasus.

Tabel 1. Sebaran kasus luka tembak di Sulawesi Utara kurun waktu Januari 2012-Juli 2017

\begin{tabular}{ccc}
\hline Tahun & $\begin{array}{c}\text { Jumlah } \\
\text { kasus }\end{array}$ & $\%$ \\
\hline 2012 & 3 & $21,43 \%$ \\
2013 & 1 & $7,14 \%$ \\
2014 & 1 & $7,14 \%$ \\
2015 & 2 & $14,29 \%$ \\
2016 & 5 & $35,71 \%$ \\
2017 & 2 & $14,29 \%$ \\
Total & 14 & $100 \%$ \\
\hline
\end{tabular}

Tabel 2. Sebaran karakteristik sosiodemografi luka tembak di Sulawesi Utara periode Januari 2012-Juli 2017

\begin{tabular}{lcc}
\hline Karakteristik & Jumlah & $\%$ \\
\hline Jenis kelamin & & \\
$\quad$ Laki-laki & 14 & 100 \\
$\quad$ Perempuan & 0 & 0 \\
Usia (tahun) & & \\
$<5$ & 0 & 0 \\
$5-14$ & 0 & 0 \\
$15-24$ & 3 & 21,43 \\
$25-44$ & 7 & 50 \\
$45-64$ & 0 & 0 \\
$\geq 65$ & 0 & 0 \\
Tidak ada & 4 & 28,57 \\
data & & \\
Lokasi kejadian penembakan & \\
$\quad$ Manado & 12 & 85,71 \\
Minahasa & 1 & 7,14 \\
Induk & & 7,14 \\
$\quad$ Bolaang & 1 & \\
Mongondow & &
\end{tabular}

Karakteristik kondisi korban penembakan dapat dilihat pada Tabel 3. Dari keseluruhan kasus, 7 (50\%) korban dalam keadaan hidup dan $7(50 \%)$ korban meninggal dunia. Hanya 8 kasus yang dibawa ke Bagian Kedokteran Forensik dan
Medikolegal maupun Bagian Ilmu Bedah RSUP Prof. dr. R. D. Kandou, Manado. Dari 8 kasus tersebut, 7 kasus meninggal dunia dan 1 kasus korban dalam keadaan hidup.

Tabel 3. Sebaran karakteristik luka tembak di Sulawesi Utara periode Januari 2012-Juli 2017 berdasarkan kondisi korban

\begin{tabular}{ccc}
\hline Karakteristik & Jumlah & \% \\
\hline Kondisi korban & & \\
Hidup & 7 & 50 \\
Meninggal & 7 & 50 \\
\hline
\end{tabular}

Karakteristik jenis luka tembak dapat dilihat pada Tabel 4 . Terdapat 8 kasus yang dibawa ke RSUP Prof. Dr. R. D. Kandou Manado (Bagian Kedokteran Forensik dan Medikolegal serta Bagian Bedah). Dari 8 kasus tersebut, 7 kasus memiliki data jenis luka tembak sedangkan 1 kasus tidak memiliki data jenis luka tembak. Dari 7 kasus yang memiliki data jenis luka tembak, seluruhnya (100\%) adalah luka tembak masuk. Satu dari 7 (semua) luka tembak masuk tersebut (14,29\%) merupakan luka tembak keluar yakni suatu keadaan dimana peluru yang masuk masih memiliki daya kekuatan hingga menembus keluar bagian tubuh lainnya.

Tabel 4. Sebaran karakteristik kasus luka tembak di Sulawesi Utara periode Januari 2012-Juli 2017 berdasarkan jenis luka

\begin{tabular}{lcc}
\hline Karakteristik & Jumlah & \% \\
\hline Jenis luka & & \\
Luka tembak masuk* & $7 / 7$ & 100 \\
Luka tembak keluar** & $1 / 7$ & 14.29 \\
\hline
\end{tabular}

*dari 7 kasus yang dibawa ke Bagian Kedokteran Forensik dan Medikolegal atau di Bagian Bedah RSUP Prof. Dr. R. D. Kandou, Manado yang memiliki data lengkap tentang jenis luka tembak **dari 7 kasus luka tembak masuk, satu di antaranya disertai dengan luka tembak keluar (tembus)

\section{BAHASAN}

Dari penelitian retrospektif selama kurun waktu 2012-2017 di Sulawesi Utara, ditemukan 14 kasus luka tembak. Kasus terbanyak terjadi pada tahun 2016, 
sejumlah 5 kasus. Dibandingkan dengan daerah lain, kejadian luka tembak di Sulawesi Utara lebih sedikit. Menurut laporan Komisi untuk Orang Hilang dan Tindak Kekerasan (KontraS), di Provinsi Papua tercatat sebanyak 98 kasus penembakan dalam kurun waktu 3 tahun, sedangkan di Provinsi Nanggroe Aceh Darussalam, tercatat sejumlah 22 kasus penembakan dalam kurun waktu 3 tahun. ${ }^{4}$ Berdasarkan data Bareskrimum Polda Sulut, semua kasus luka tembak dilakukan oleh aparat keamanan. Hal ini kemungkinan disebabkan karena bertambah maraknya kasus kejahatan yang terjadi di kalangan masyarakat. Seiring perkembangan jaman, diduga para pelaku kejahatan semakin berani memberikan aksi perlawanan yang dapat mengancam keselamatan berbagai pihak. Keadaan ini menyebabkan aparat keamanan melakukan penembakan terhadap pelaku kejahatan sesuai standar operasional prosedur (SOP) yang berlaku. Tidak terdapat kasus luka tembak oleh warga sipil atau masyarakat. Umumnya kasus kekerasan yang terjadi di kalangan masyarakat masih menggunakan senjata tajam atau senjata tradisional lainnya. Untuk membuktikan hal ini, dibutuhkan penelitian lebih lanjut.

Dari data yang dikumpulkan, didapatkan bahwa keseluruhan kasus penembakan terjadi pada laki-laki. Hal ini kemungkinan disebabkan beberapa faktor. Secara teori, laki-laki memiliki sex determining region $Y$ (SRY), yang dapat mempengaruhi tingkat agresifitasnya dalam merespon suatu hal. Laki-laki memiliki tingkat agresifitas yang jauh lebih tinggi dibandingkan perempuan. Faktor tersebut turut mempengaruhi respon laki-laki terhadap suatu kondisi terutama bila dipicu dengan munculnya stresor. Dalam hal ini, laki-laki menjadi lebih rentan terlibat dalam berbagai kasus kriminal dan kasus penembakan.,

Dari data usia, diperoleh data bahwa kasus penembakan lebih banyak terjadi pada usia produktif. Pada usia produktif, setiap individu memiliki tingkat aktivitas yang tinggi. Selain tingginya aktivitas, kelompok usia produktif memiliki kemungkinan berinteraksi lebih banyak dengan berbagai kalangan. Di samping itu, kelompok usia ini juga rentan mengalami berbagai hal negatif yang dipengaruhi oleh lingkungan, pola sosialisasi antar individu serta pengaruh dari stresor yang ada dalam diri masing-masing. Pada usia ini juga setiap individu mencapai titik kebebasan untuk menentukan lingkungan pergaulan serta pola interaksi sosial. Berbagai permasalahan dan hal-hal negatif yang terjadi di luar lingkup keluarga, tidak dapat terkontrol. Oleh sebab itu, pada usia produktif, banyak ditemukan kasus-kasus kriminalitas.

Bila dilihat dari data lokasi kejadian penembakan, didapatkan perbedaan yang cukup signifikan antara masing-masing lokasi. Data yang diperoleh menunjukkan bahwa terdapat 12 kasus penembakan di kota Manado, 1 kasus di Minahasa Induk dan 1 kasus di Bolaang Mongondow. Dominannya kasus penembakan di kota Manado, kemungkinan dipengaruhi oleh beberapa faktor. Ditilik dari faktor sosiodemografis, Kota Manado merupakan ibukota Provinsi Sulawesi Utara dan termasuk dalam kategori kota besar. ${ }^{8}$ Probabilitas terjadinya berbagai tindak kriminalitas di kota besar juga semakin tinggi. Didukung oleh faktor pertumbuhan penduduk dan sosial perekonomian, memungkinkan kota Manado semakin rentan terhadap berbagai tindak kriminalitas.

Dari keseluruhan kasus, ditemukan 7 korban dalam keadaan hidup dan 7 korban meninggal dunia. Probabilitas korban hidup atau meninggal bergantung pada beberapa faktor. Pertama, faktor perlawanan dan agresivitas pelaku kriminalitas. Semakin besar perlawanan dan sikap agresif yang ditunjukkan oleh pelaku, maka semakin besar pula kemungkinan aparat keamanan me-lontarkan tembakan dari senjata api sesuai dengan standar operasional prosedur (SOP) yang berlaku. Kedua, jenis tembakan yang dilontarkan dari senjata api. Jarak tembak atau jarak moncong senjata dengan tubuh korban dapat mempengaruhi jenis luka yang terbentuk. Ketiga, jenis luka 
tembak dan manifestasi klinis yang timbul akibat penembakan dari senjata api.

Dari 14 kejadian luka tembak yang ditemukan, hanya 8 kasus yang dibawa ke Bagian Kedokteran Forensik dan Medikolegal maupun Bagian Ilmu Bedah RSUP Prof. dr. R. D. Kandou, Manado. Korban penembakan lainnya dibawa ke rumah sakit polisi untuk dilakukan pemeriksaan lebih lanjut maupun otopsi apabila korban dalam keadaan meninggal dunia. Dari 8 kasus tersebut, 7 kasus meninggal dunia dan 1 kasus dalam keadaan hidup. Dari 7 kasus yang meninggal dunia, 6 di antaranya memiliki data jenis dan lokasi luka tembak. Untuk 1 kasus korban hidup, tersedia data jenis dan lokasi luka tembak. Lokasi luka tembak dominan mengenai bagian lengan atas (3 kasus), bagian dada (2 kasus), bagian kepala (1 kasus) dan bagian paha (1 kasus). Adapun jenis luka tembak yang ditemukan yaitu luka tembak masuk dan luka tembak keluar. Dari 7 kasus yang memiliki data jenis luka tembak, seluruhnya adalah luka tembak masuk. Satu di antara 7 kasus luka tembak masuk merupakan luka tembak keluar karena diidentifikasi masuk dan menembus bagian tubuh lainnya. Luka tembak masuk merupakan suatu keadaan dimana peluru masuk pada suatu objek dan tidak keluar. Salah satu ciri dari luka tembak masuk adalah terbentuknya kelim lecet (abrasio ring). Terjadinya kelim lecet diakibatkan oleh gerakan rotasi peluru, hingga timbul gesekan antara badan peluru dengan tepi robekan kulit. Sedangkan luka tembak keluar merupakan suatu keadaan dimana peluru yang ditembakkan dari senjata api mengenai tubuh korban dan kekuatannya masih cukup untuk menembus keluar bagian tubuh lainnya. Ciri khas utama yang membedakannya dengan luka tembak masuk yakni tidak ditemukannya kelim lecet pada luka tembak keluar. ${ }^{9,10}$ Kematian akibat luka tembak umumnya disebabkan oleh kerusakan organ, pembuluh darah, sistem saraf pusat, serta terjadinya perdarahan masif akibat luka tembak yang terjadi. $^{11}$

Menurut data Bareskrimum Polda
Sulut, belum ada laporan terkait kasus penembakan yang dilakukan oleh warga sipil. Kasus-kasus penembakan yang terjadi di Sulawesi Utara sendiri kebanyakan dilakukan oleh anggota kepolisian selaku aparat keamanan yang melakukan pengamanan sesuai dengan SOP yang berlaku. Tata cara penggunaan senjata api bagi anggota polisi diatur dalam Perkapolri No. 8 Tahun 2009 tentang Implementasi Prinsip dan Standar Hak Asasi Manusia dalam Penyelenggaraan Tugas Kepolisian Negara Republik Indonesia serta Perkapolri No. 1 tahun 2009 tentang Penggunaan Kekuatan dalam Tindakan Kepolisian. Berdasarkan Pasal 47 Perkapolri 8/2009 disebutkan bahwa, penggunaan senjata api hanya boleh digunakan bila benar-benar diperuntukkan untuk melindungi nyawa manusia. Senjata api bagi petugas hanya boleh digunakan dalam hal menghadapi keadaan luar biasa, membela diri dari ancaman kematian dan/atau luka berat, membela orang lain terhadap ancaman kematian dan/atau luka berat, mencegah terjadinya kejahatan berat atau yang mengancam jiwa orang, menahan, mencegah atau menghentikan seseorang yang sedang atau akan melakukan tindakan yang sangat membahayakan jiwa dan menangani situasi yang membahayakan jiwa, dimana langkah-langkah yang lebih lunak tidak cukup. Pada pasal 8 ayat [1] Perkapolri 1/2009 disebutkan bahwa penggunaan senjata api boleh dilakukan apabila tindakan pelaku kejahatan atau tersangka dapat secara segera menimbulkan luka parah atau kematian bagi anggota Polri atau masyarakat, anggota Polri tidak memiliki alternatif lain yang beralasan dan masuk akal untuk menghentikan tindakan/ perbuatan pelaku kejahatan atau tersangka tersebut dan anggota Polri sedang mencegah larinya pelaku kejahatan atau tersangka yang merupakan ancaman segera terhadap jiwa anggota Polri atau masyarakat. Pada prinsipnya, penggunaan senjata api merupakan upaya terakhir untuk menghentikan tindakan pelaku kejahatan atau tersangka. Jadi, penggunaan senjata api oleh polisi hanya digunakan saat keadaan adanya ancaman terhadap jiwa manusia. Sebelum 
menggunakan senjata api, polisi harus memberikan peringatan yang jelas. Tata cara pemberian peringatan diatur dalam pasal 48 Perkapolri 8/2009. Prosedur pertama yakni menyebutkan dirinya sebagai petugas atau anggota Polri yang sedang bertugas, memberi peringatan dengan ucapan secara jelas dan tegas kepada sasaran untuk berhenti, angkat tangan, atau meletakkan senjatanya dan memberi waktu yang cukup agar peringatan dipatuhi. Sesuai dengan pasal 15 Perkapolri $15 / 2009$, sebelum melepaskan tembakan, polisi juga harus memberikan tembakan peringatan ke udara atau ke tanah dengan kehati-hatian tinggi dengan tujuan untuk menurunkan moril pelaku serta memberi peringatan sebelum tembakan diarahkan kepada pelaku. Pengecualiannya yaitu dalam keadaan yang sangat mendesak di mana penundaan waktu diperkirakan dapat mengakibatkan kematian atau luka berat bagi petugas atau orang lain di sekitarnya, peringatan tidak perlu dilakukan. Jika ada pihak yang dirugikan atau keberatan karena penggunaan senjata api, petugas polisi yang bersangkutan wajib membuat penjelasan secara terperinci tentang alasan penggunaan senjata api, tindakan yang dilakukan dan akibat tindakan yang telah dilakukan. Selain itu, setelah menggunakan senjata api, polisi harus membuat laporan terperinci mengenai evaluasi pemakaian senjata api. Laporan inilah yang akan digunakan untuk bahan pertanggung-jawaban hukum penerapan penggunaan kekuatan, serta sebagai bahan pembelaan hukum dalam hal terjadi gugatan pidana/perdata terkait penggunaan kekuatan yang dilakukan oleh anggota Polri yang bersangkutan. Pada prinsipnya, setiap individu anggota Polri wajib bertanggung jawab atas pelaksanaan penggunaan kekuatan (senjata api) dalam tindakan kepolisian yang dilakukannya. 12,13

Berdasarkan data Bareskrimum Polda Sulut, tercatat penggunaan senjata api yang dilakukan dalam penembakan pada proses penangkapan adalah senjata api berjenis laras pendek, jenis revolver dengan kaliber 38. Jenis senjata api revolver kaliber 38 secara undang-undang dikatakan kepemilikannya legal bagi para anggota kepolisian. Di Sulawesi Utara sendiri, belum ada laporan peredaran senjata api secara ilegal maupun senjata api rakitan atau selundupan. Dapat ditarik kesimpulan, bahwa penembakan-penembakan yang tercatat sebagai kasus luka tembak sepenuhnya dilakukan menggunakan senjata api jenis revolver kaliber 38 yang merupakan milik resmi anggota kepolisian.

\section{SIMPULAN}

Berdasarkan hasil penelitian dapat disimpulkan bahwa di Sulawesi Utara, kasus luka tembak ditemukan pada jenis kelamin laki-laki, umumnya usia produktif, dengan luka tembak masuk.

\section{SARAN}

Dibutuhkan kerja sama yang berkesinambungan dengan pihak kepolisian terkait penelusuran kasus penembakan melalui data kronologis kasus dari kepolisian agar dapat diketahui lebih mendalam tentang gambaran kasus penembakan di Sulawesi Utara.

Diperlukan penelitian lanjutan untuk mencari hubungan antara variabel yang ada serta dengan jangkauan pengambilan data yang lebih luas mencakup rumah sakit kepolisian daerah.

Ucapan terima kasih ditujukan kepada Bareskrimum Kepolisian Daerah Sulawesi Utara dan seluruh pihak yang telah membantu penulis dalam menyelesaikan penelitian ini.

\section{DAFTAR PUSTAKA}

1. World Health Organization. Small arms and global health; July 2001 [cited 2017 Aug 7]. Available from: http://apps. who.int/iris/bitstream/10665/66838/1/ WHO_NMH_VIP_01.1.pdf

2. Wendy C. Small arms and light weapons: A public health approach; Spring 2002 [cited 2017 Aug 7]. Available from: https://www.brown.edu/initiatives/jour nal-worldaffairs/sites/brown.edu. initiatives.journal-world-affairs/files/ private/articles/9.1_Cukier.pdf 
3. Michael S, David R. Forensic Pathology of Trauma. New Jersey: Humana Press. 2007.

4. Komisi untuk Orang Hilang dan Tindak Kekerasan (KontraS). Laporan Penggunaan Senjata Api dalam Kekerasan. Jakarta, 2013.

5. Kristanto E, Mallo JF, Yudhistira A. Cedera akibat kecelakaan lalu lintas di Kota Manado [Skripsi]. Manado: Fakultas Kedokteran Universitas Sam Ratulangi; 2009.

6. Aggressive behaviour: contributions from genes on the Y chromosome [internet]. 2005 [cited 2017 Nov 9]. Available from: https://www.ncbi. nlm.nih.gov/ pubmed/16206873

7. Umboh R, Mallo N, Tomuka D. Pola luka pada korban mati akibat senjata api di Bagian Ilmu Kedokteran Forensik Medikolegal FK Unsrat - RSUP Prof. Dr. R. D. Kandou Manado periode Januari 2007-Desember 2013 [Skripsi]. Manado. Universitas Sam Ratulangi; 2015.

8. Migrasi dan kepadatan penduduk di Kota
Manado [internet]. 2013 [cited 2017 Nov 9]. Available from: http://sulut. bkkbn.go.id/AnalyticsReports/Deybie_ 01.pdf

9. Abdul I. Pedoman Ilmu Kedokteran Forensik. Jakarta: Bina Rupa Aksara, 2014.

10. Iwan A, Nila N, Muhamad A. Ilmu Kedokteran Forensik dan Mediko-legal. Jakarta: Raja Grafindo Persada, 2017.

11. Rull G. Gunshot injuries. Emergency and Medicine Trauma [internet]. 2014 [cited 2017 Nov 9]. Available from: https://patient.info/doctor/gunshotinjuries

12. Kepolisian Negara Republik Indonesia. Peraturan Kepala Kepolisian Negara Republik Indonesia No. 8 Tahun 2009 tentang Implementasi Prinsip dan Standar Hak Asasi Manusia dalam Penyelenggaraan Tugas Kepo-lisian Negara Republik Indonesia. 2009.

13. Kepolisian Negara Republik Indonesia. Peraturan Kepala Kepolisian Negara Republik Indonesia No. 1 tahun 2009 tentang Penggunaan Kekuatan dalam Tindakan Kepolisian. 2009. 